\title{
GIS based beach sand budget analysis through seasonal beach profiling using cartographic techniques
}

\author{
Manik Das Adhikari ${ }^{1} \cdot$ Sabyasachi Maiti $^{1} \cdot$ Susanta Patra $^{2} \cdot$ Adarsa Jana $^{1}$ • \\ Soumya Kanti Maiti ${ }^{1} \cdot$ Arnab Sengupta $^{1}$
}

Received: 28 February 2016/Accepted: 18 March 2016/Published online: 15 April 2016

(C) Springer International Publishing Switzerland 2016

\begin{abstract}
Seasonal morphological variations and effect of oceanographic processes such as erosion or accretion along beaches are important aspects to understand the sand budget. The nature of the beach and their seasonal cyclic changes are probable reasons of seasonal morphological variations. The primary objective of the present study is to estimate coastal beach sand budget using Geoinformatics techniques. The study area is $113 \mathrm{~km}$ long coastal belt covering parts of Midnapore-Balasore coast. The field data has been collected using GPS and Theodolite, following standard cartographic techniques. Besides, Remote Sensing and GIS techniques have been used in identifying the coastal features, mapping and spatial analysis. Therefore, eighteen beach profiles have been taken during the post and pre-monsoon seasons of the year 2008 and 2009. Within the specific zones, beach erosion and/or accumulation between post and pre-monsoon season has been quantified. The result shows that up to pre-monsoon season, the beach is significantly recovered with gradual decrease in beach gradient. Further, along each profile Digital Elevation Models corresponding to post and pre monsoons periods have been generated, which has subsequently utilized in the estimation of beach recovery along each profile and also estimation of beach sand budget of the study region.
\end{abstract}

Keywords Post and pre-monsoon seasons . Geoinformatics techniques · Beach profiling $\cdot$ Beach

Manik Das Adhikari

rsgis.manik@gmail.com

1 Department of Geology and Geophysics, Indian Institute of Technology Kharagpur, Kharagpur, West Bengal, India

2 Department of Geography, Subarnarekha Mahavidyalaya, Vidyasagar University, Medinipur, West Bengal, India erosion/accumulation · GPS · Cartographic technique · Digital elevation model $\cdot$ Beach sand budget

\section{Introduction}

The interpretation of coastal dynamics in various forms has attracted many early researchers (Anthony et al. 2006; Sener et al. 2009; Cracknell 1999; Cracknell and Hayes 1991; Huang et al. 1991). Beach profile studies give information on cyclic/seasonal morphological changes in the coastal area which are essential to identify the erosional and depositional features, which in turn help to understand changes in oceanographic processes in the coastal areas. (Anthony et al. 2006; Bhattacharya et al. 2003; Chang 2007; Ganesan and Gaonkar 2006; Ikeda and Dobson 2005; Maiti and Bhattacharya 2009; Pethick 1990; Paul 2002; Pacheco et al. 2008; Ramasamy and Kasturirangan 2005; Ramana Murthy et al. 2008; Selby 1985). The foreshores of the beaches including the surf zone are very interesting as they keep changing time and again. The dynamic characteristics of the beach are varying temporarily with changing wave conditions during post-monsoon and pre-monsoon seasons having different environmental conditions. Therefore, to assess the dynamic behavior of the coastal region for pre monsoon and post-monsoon season it is essential to carry out seasonal beach profiling. In the present study, we have done extensive field survey for obtaining the beach profiles of post-monsoon and pre-monsoon seasons along $113 \mathrm{~km}$ long coastal stretch with variable geomorphology between Digha Coastal Plain and Subarnarekha Delta Plain for computation of volume of sand/sand accretion/erosion along the beaches. 


\section{Study area}

The present study region cover the Digha Coastal Plain and Subarnarekha Delta Plain within the district of Midnapur, West Bengal and Balasore district of Orissa, India respectively, is situated between tectonically active Ganga Delta and wave dominated Subarnarekha estuary. It extends about $113 \mathrm{~km}$ from Rasulpur River, Midnapur District, West Bengal in the northeast to Kakrapali inlet, Balasore District, Orissa in the southwest. The entire study area is covered by the sand dunes and sandy beaches and is bounded by $21^{\circ} 30^{\prime} \mathrm{N}-21^{\circ} 48^{\prime} \mathrm{N}$ latitudes and $87^{\circ} 12^{\prime} \mathrm{E}-$ $87^{\circ} 54^{\prime} \mathrm{E}$ longitudes as depicted in Fig. 1. The depositional nature of the coastal area is considered to be the product of several geomorphological processes involving multiple cycles of deposition (Rao et al. 2008). However, it is observed that the major part of the study area is dominated by wind deposits sand at the time of pre-monsoon except in the front of tidal creak at Talsari and near Subarnarekha estuary.

The region is located in a tropical hot humid monsoon climatic belt. Therefore, the pre-monsoon season extent from mid-February to mid-May is characterized by moderate rain. The southwest winds usually generate moderate tidal waves about $0.3-1.5 \mathrm{~m}$ high. Conversely, during November to midFebruary i.e. the post-monsoon season dominated by the northwest monsoon presents a reversal of air movement and the tidal waves are generally small with a height lower than $0.5 \mathrm{~m}$. The longshore current commonly flows from the south to the northwest during this monsoonal season. However, the tidal wave heights have been generated of more than $5 \mathrm{~m}$ during the monsoon season.
Fig. 1 Location map of the study area extends from Rosulpur River, northeastern to Kankrapali inlet, southwestern

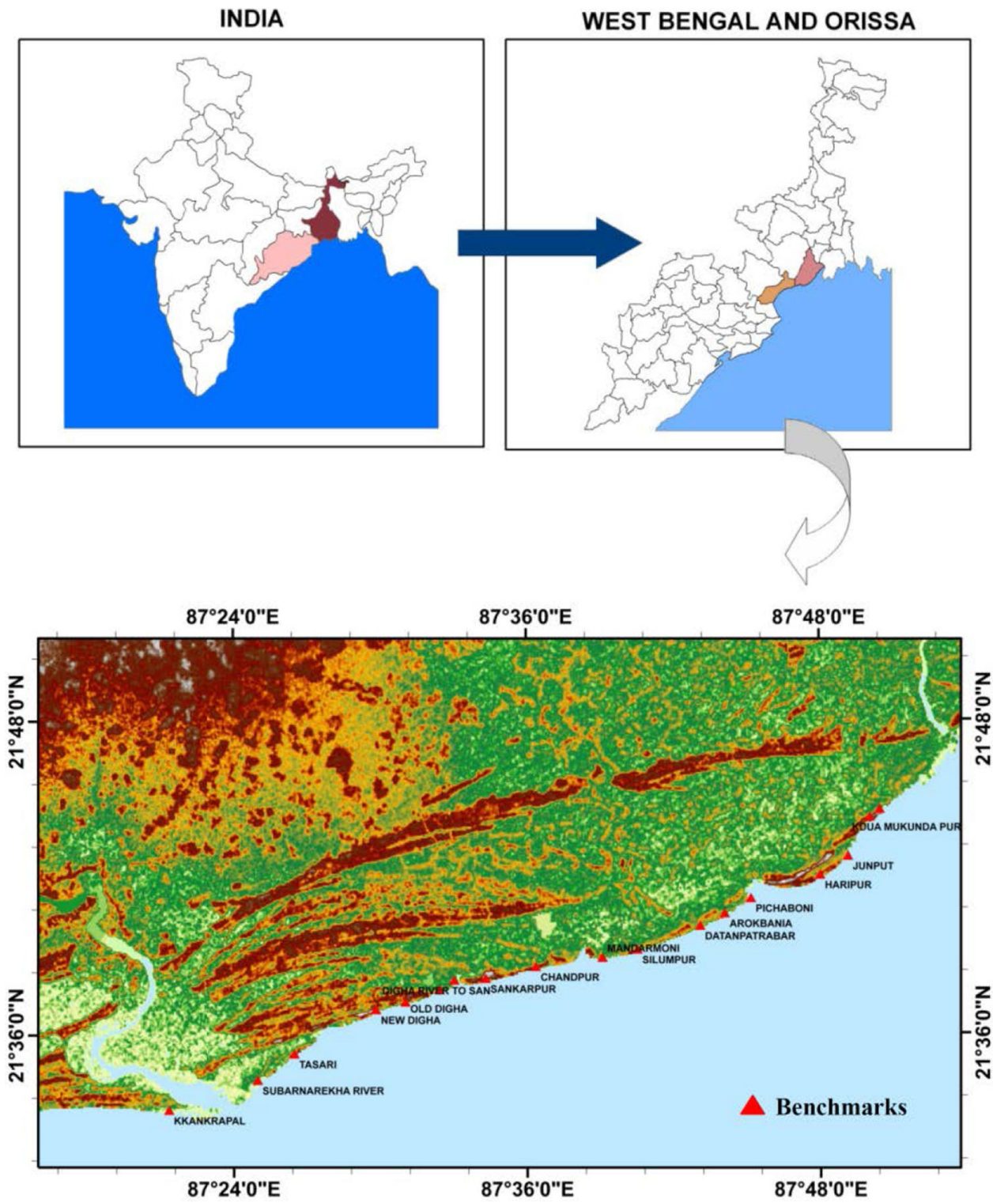




\section{Materials and methodology}

The primary source of the data is the Landsat ETM+, which is downloadable from USGS data archive (www. wist.echo.nasa.gov). Multi temporal Landsat ETM + data have been acquired over the period of pre-monsoon and post-monsoon 2009. The Survey of India (SOI) topographical maps on 1:50,000 scales have been used as ancillary data. The area is covered by five Survey of India (SOI) toposheets of 1973 viz., Nos. 73O/2, 730/6, 73O/10, $730 / 13$ and $730 / 14$. The selected satellite images have been georeferenced with the Survey of India toposheets as mention earlier, which have been used as the Reference Base Map. In the present study, SRTM digital elevation model has been used to identify the regional depositional features in the coastal region. To assess the beach sand budget, we have used pre- and post-monsoonal beach profile as an input for the GIS modeling. The major objectives the present study are as follows: (1) to understand the environmental conditions in the areas of potential deposits and erosions, (2) To estimate the beach erosion and beach recovery during pre-and post-monsoon season, (3) To correlate beach gradient erosion and wave action, and (4) To estimate the beach sand budget per unit surface area $\left(\mathrm{m}^{3} / \mathrm{m}^{2}\right)$ during the pre-and post-monsoon season.

\section{Field investigation}

The beach profile is one the significance geographic features of coastal morphology. The term 'beach profile' refers to a cross-sectional trace of the beach perpendicular to the high-tide shoreline and extends from the backshore cliff or dune to the inner continental shelf or a location where waves and currents do not transport sediment to and from the beach (Chrzastowski 2005). The profile shape is variable, depending on the time of year within the annual beach cycle and, also, the elapsed time after a storm. Waves, water level, and sediment grain size are the main controlling factors of beach profile Shape (Dean 1977). Digha Coastal Plain and Subarnarekha Delta Plain are sandy beaches that normally flatter than shingle beach and their cross-profile are different in post-and pre-monsoon seasons (Maiti and Bhattacharya 2009). As the main controller of seasonal beach profile is wave steepness, the amount of material piled up or moved down a beach varies with the type of wave. The steep wave comedowns the beach by moving sediment seaward by their powerful backwash. Similarly, flat waves shift sediment landward, steepening the beach, but this increase in gradient will eventually shorten the wavelength, making the wave more destructive (Bryant 1986; Bhattacharya et al. 2003). In premonsoon, when constructive waves are predominating, a berm is built up at the limit of wave action. Sometimes, several berms may be observed, related to a spring-neap tide sequence. In post-monsoon, storms produce much flatter profiles, especially on sandy beaches.

The seasonal beach profiles have been taken up along the Balasore and Midnapore coast for understanding the seasonal variations of the beach morphology. For the purpose, we have selected eighteen sites viz. Haripur, KaduaMukundpur-1, Dadanpatrabari, Arokbania, Pichhabani, Mandarmoni, Kadua-Mukundpur-2, Silampur, Junput, Shankarpur, Chandpur, Talsari, Subarnarekha River Mouth, New Digha, Old Digha, Knakrapali, Digha Mahona, Digha River to Sankarpur Forest based on the seasonal accretion and erosional behavior of the beach morphology observed from different satellite imagery. Therefore, we have taken beach profile mainly at two season i.e. post-and pre-monsoon.

Firstly, we have establish benchmark by GPS and then collected field data by the survey instrument i.e. Theodolite. GPS has been used for obtaining the geographical co-ordinates (Horizontal control) of the permanent benchmarks and the start and end point of a beach profile. A Transit Theodolite (level instrument) and a leveling staff have been used for carrying out the beach profiling at all the selected eighteen sites. It is an instrument used for measuring horizontal, vertical angles and elevation more precisely and accurately than any other instrument. The instrument is fitted with a telescope in order to facilitate the sighting of distance objects. It is frequently used in different types of works such as traverse, triangulation, computation of elevations and depressions of distant and near objects (Singh and Singh 1950). For leveling, a stretch of beach the instrument is set up on the tripod stand at a point "L" and with the help of leveling -screws, the instruments is leveled up so that when the telescope is rotated the bubble in the spirit level always remain in the center. A leveling staff is held at the start of beach (high tide level) at "Y". The telescope is directed on the leveling staff and the height where the cross-wires intersect the staff is noted. The staff is moved to another point up the beach to " $\mathrm{X}$ " and another reading is taken. The difference between these two reading gives the difference of level between these two points on the beach. Next, the instrument is moved to another point " $\mathrm{P}$ " on the beach and similar reading is taken. In this way, the relative height of points on the beach is determined and a beach profile is drawn. If the height above sea level of the point "M" or any other point on the beach is known, it is obvious that the height above the sea level of all the points can be found out by simple addition or subtraction as shown in Fig. 2. A total of 36 profiles have been surveyed at different locations i.e. two profiles at each location for post and pre-monsoon season of 2009. 
Fig. 2 Schematic diagram of surveying method used to entry data in the field

Fig. 3 The logical flow diagram for the estimation of reduce level from the field data
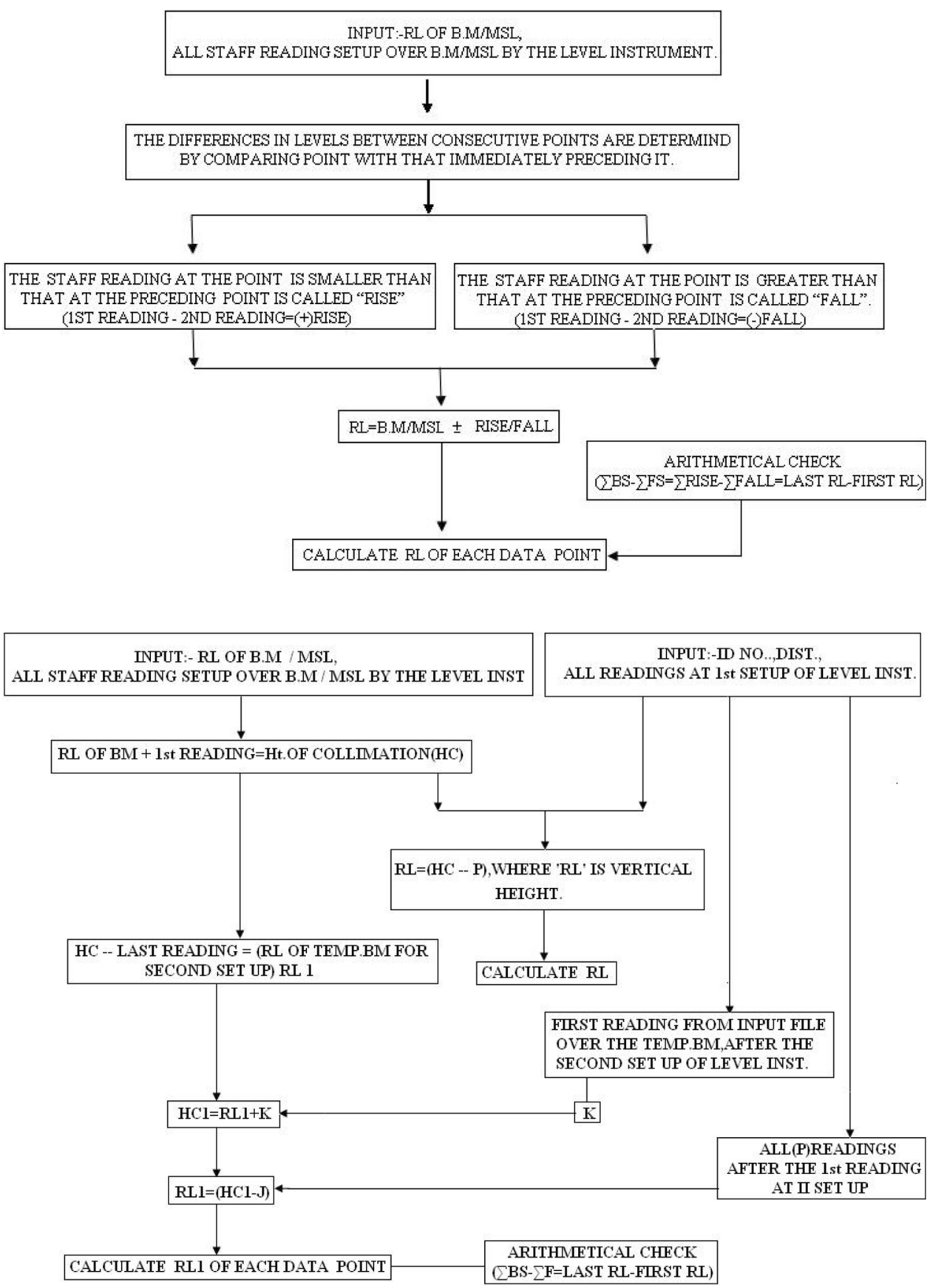

The vertical control is essential to provide the height information for beach profiling. At all the selected sites of study, benchmarks have been established by GPS. The tide level at the time of observation was later processed to get the vertical height of that point from the mean sea level. The vertical height (above or below mean sea level) thus obtained at the tide level point is then transferred to the benchmark (which was selected perpendicular to the coast) using level instrument. The benchmarks, thus fixed formed the base for comparing the beach profiles studied at post and pre-monsoon. The tidal data was taken from
WXTide32, MA 02139, USA. The beach profiling was then carried out at all selected locations using Transit Theodolite and a leveling staff, at every $5 \mathrm{~m}$ intervals. Apart from this, extreme care was taken to take field measurements at such points, where sudden rise and fall existed, on the path of profile. The profiling was started from sea to shoreward. The last reading was taken in the dune zone and at that observation; the exact time was noted to read the corresponding tide, Wave parameters like, wave height, water level, wave period, were also measured. The collected field data was taken to laboratory for further processing. 

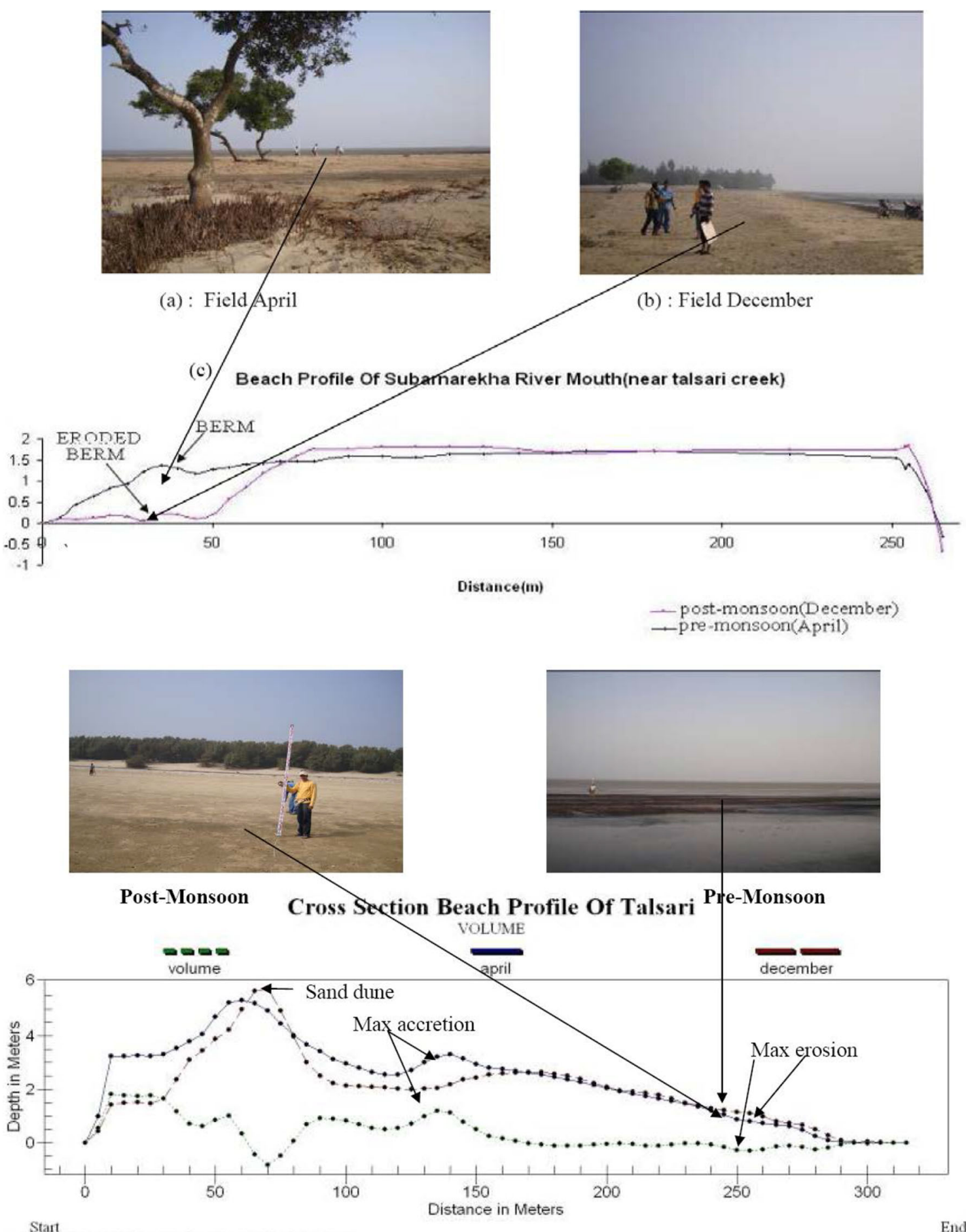

Fig. 4 Seasonal change of cross-sectional beach profile along the Subarnakeha River Mouth, Talsari, Digha Mohana, Junput and Haripur coastal region observed during the field survey

The reduced level over the bench mark (beach profile, where the profile starts) has been added with the first staff reading taken over it, which forms the height of collimation (H.C.) of the instrument. From this H.C., all the successive staff readings (taken at regular distance interval along the profile) have been deducted to get the vertical heights (called reduced level (R.L.) in survey terms). Figure 3 depicted the details procedure to obtained the RL by considering: (1) R.L. at benchmark + staff reading over the benchmark $(\mathrm{BM})=$ Height of Collimation of instrument (H.C.), (2) H.C. at first set up-successive staff readings $=$ Reduced levels (Vertical heights with respect to 

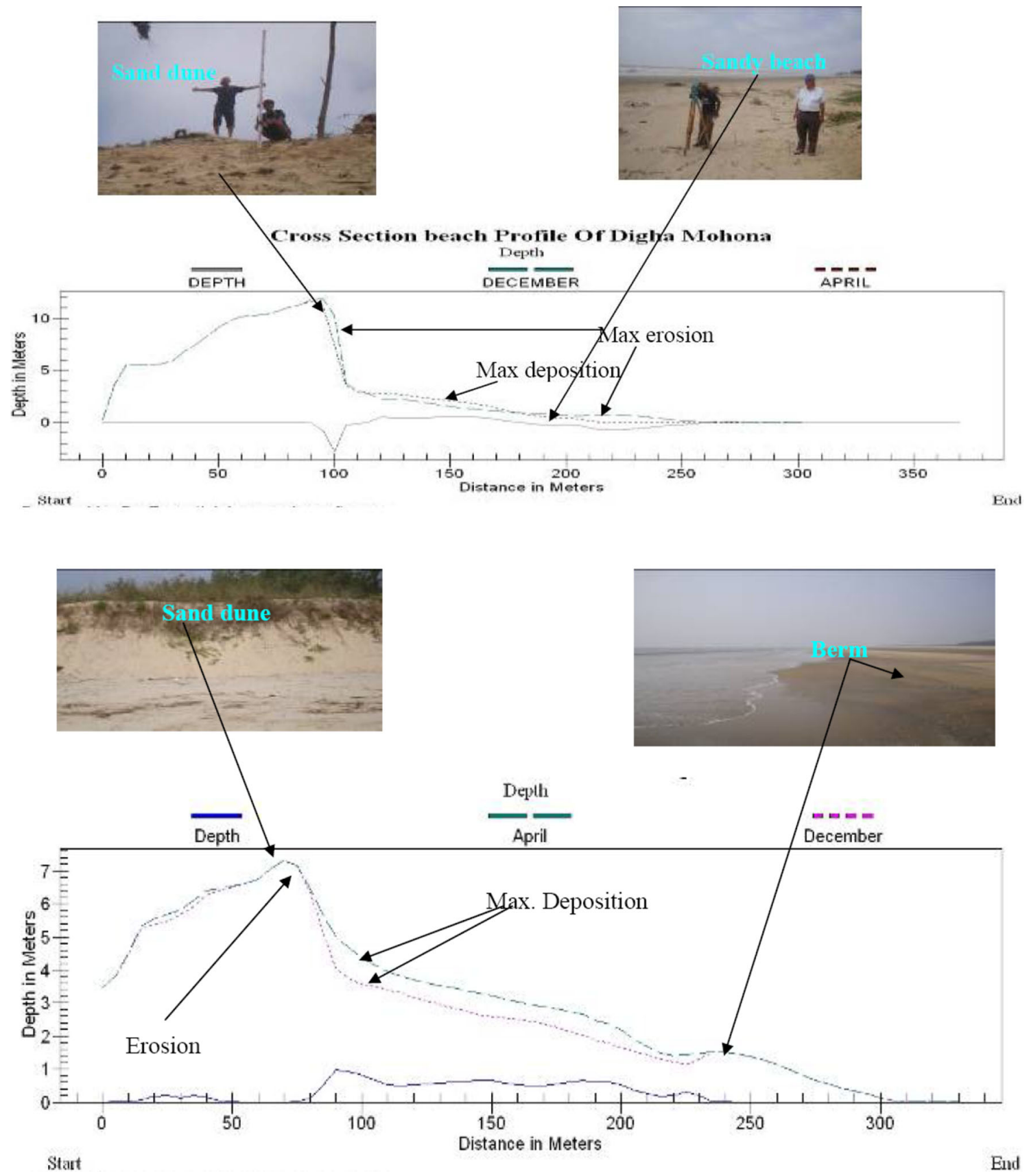

Fig. 4 continued

M.S.L.) of successive points along the profile, (3) Height of Collimation of Inst. (HC1) at second set up $=$ Reduced level of last point (Temp BM) + First staff reading (immediately after second set up) over Temporary benchmark, and (4) Reduced level of all the successive data points from second set up $=(\mathrm{HC} 1$-successive staff readings observed from second set up). In this way we have been calculated RL of pre and post-monsoon seasons of 2009 for obtaining volume of sand. Figure 4 depicts some representative beach profile at Subarnakeha River Mouth, Talsari, Digha Mohana, Junput and Haripur coastal region.

\section{GIS analysis for obtaining the volume of sand} of different GRID surface i.e. post and pre-monsoon

GIS analysis has been performed for obtaining volume of sand of different grid surface (post and pre-monsoon). Therefore, as a GIS input (elevation data of pre and post 


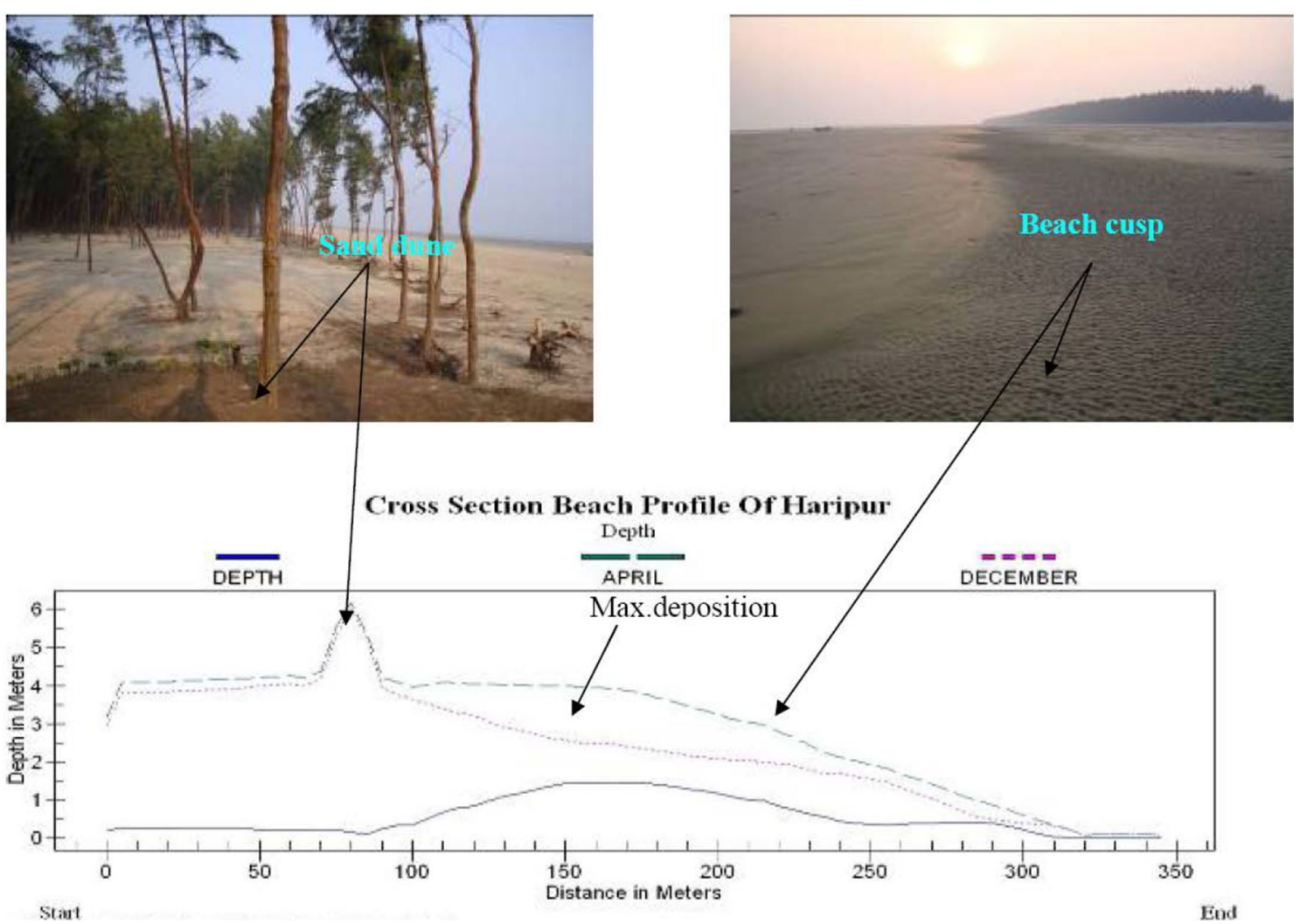

Fig. 4 continued

monsoon) we calculate latitude and longitude of each survey point/elevation data point by using the following formula as,

$$
\begin{aligned}
& \text { Longitude }=\mathrm{X}+\mathrm{SIN}(\mathrm{H} 2 * \mathrm{PI}() / 180) * \mathrm{~A} 2) \\
& \text { Latitude }=\mathrm{Y}+(\operatorname{COS}(\mathrm{H} 2 * \mathrm{PI}() / 180) * \mathrm{~A} 2)
\end{aligned}
$$

where, $\mathrm{X}$ is longitude of initial profile data point, $\mathrm{Y}$ is latitude of start profile data point, which measure by the GPS. H2 is azimuth between start and end profile data point, which is calculated by using ERDAS IMAGINE 8.5 software. A2 is the distance from start profile data point to next data point. Considering the fact that the sediment deposit is resting over the mean sea level, the sediment thickness at any point in the area is the elevation difference between the surface configuration of the sediment and the mean sea level. The grid surfaces representing the sediment thickness of the sea beach develop through inverse distance weighted method in GIS environment in order to determine the beach erosion and accretion. The detailed framework for estimation of sand volume is shown in Fig. 5.

The spatial interpolation technique i.e. Inverse Distance Weighting (IDW) is frequently used to spatially interpolate of point observation in numerous geosciences applications (e.g. Bonham-Carter 1994; Burrough and McDonnell 1998; Isaaks and Srivastava 1989; ESRI 2003). The IDW interpolator within the geographic information systems (GIS) operates on the assumption that entities in close proximity to one another are more alike than those further away via an inverse distance-weighted average of the known $\mathrm{z}$ values from a surrounding set of sample points using the following formula (ESRI 2003),

$\widehat{z}\left(S_{x y}\right)=\sum_{i=1}^{N} \lambda_{i} Z\left(S_{i}\right)$

where, $\widehat{z}\left(S_{x y}\right)$ is the predicted value for location $S_{x y}, N$ is the number of measured sample points surrounding the prediction location, $\lambda_{i}$ are the weights assigned to each measured point, $Z\left(S_{i}\right)$ is the observed value at the location $S_{\mathrm{i}}$.

The kriging weights have been derived from a simple three-parameter model i.e. semi-variogram that characterizes the spatial dependence in the known data (Meentemeyer and Moody 2000). The weights are derived such that the kriged surface will minimize the error variance, thus providing an unbiased estimate of $\mathrm{z}$ at any unsampled location within the spatial domain (Meentemeyer and Moody 2000). In the present study, the Beach elevation surface has been created by using IDW method with a power of 2 exhibits a grid surface map of the sediment thickness. Thereafter, it has been converted into a GRID format, in which each pixel represents a constant elevation. 
Fig. 5 Flow chart for obtaining volume of sand of different grid surface (post and pre-monsoon)

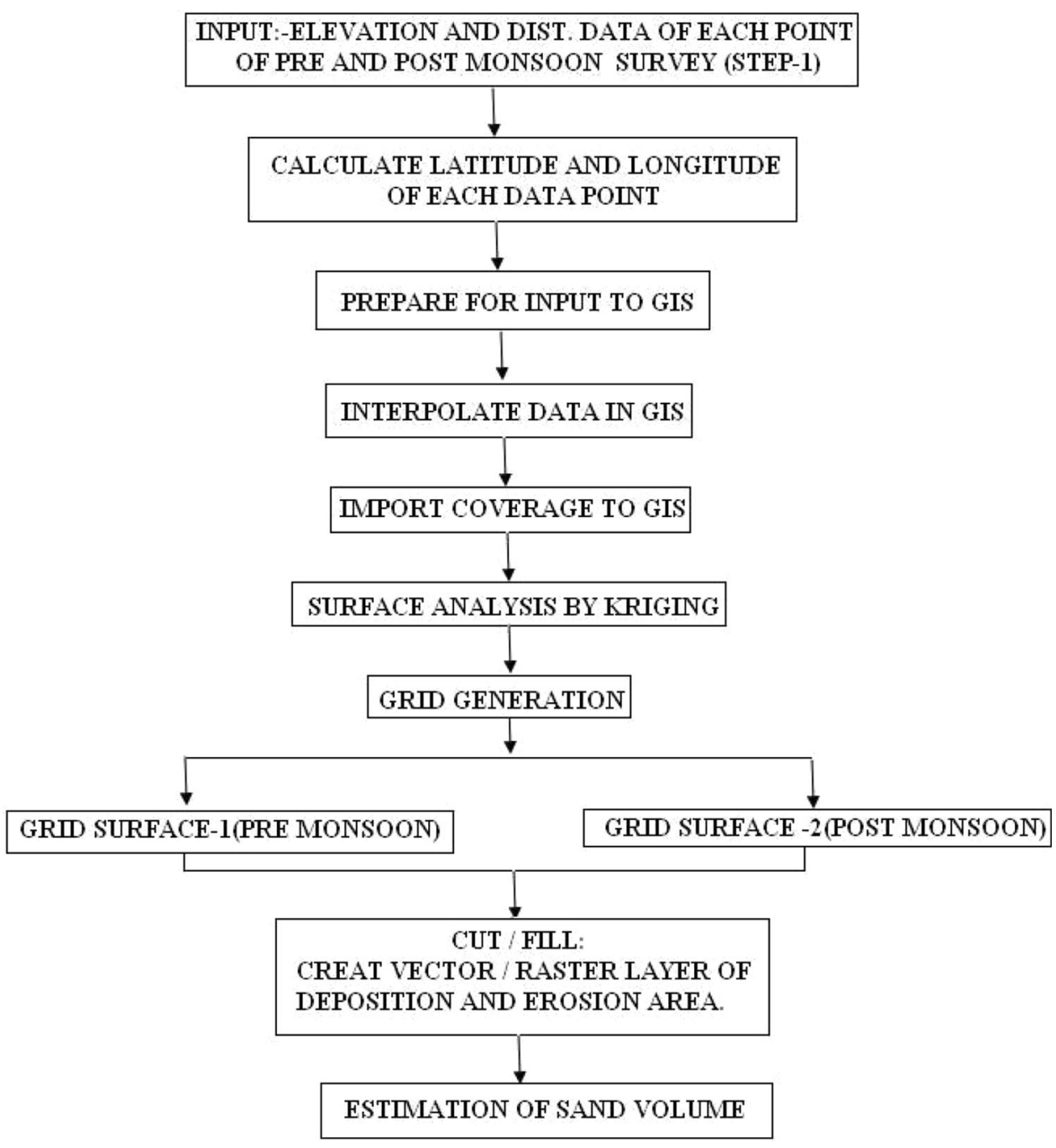

A GRID is a plain surface represented as rows and columns of raster cells, or picture elements represent an image of a ground surface. Each cell (pixel) in such matrices has a value, which is represented by a digital number in the computer (Verbyla 2002). The GRID map therefore approximates the beach topography or the sediment thickness of the coastal region. The GRID maps, being matrices of numbers, facilitate performance of statistical functions like subtractions to extract elevation differences between two surfaces (pre and post monsoon). Therefore, the Kriging of both the surface of the region are converted into raster format using 3D Analyst module of ArcGIS. Obviously, finer the resolution of the rows and columns in a grid, closer such grid represents the actual beach topography of the surface. Keeping this in view, the GRID resolution was set as 5 meters in this transformation from vector (Kriging) to raster (GRID) format for both the pre and post monsoon beach topography.

The sediment thickness at any location in the area is the difference between the pre and post monsoon surface elevation. The elevation value that a given raster cell represents in the pre monsoon beach surface of the area, if subtracted from the value of the corresponding cell in the post monsoon surface of the area, yields the thickness of the sediment at that location (Choowong et al. 2004; Dubois 1988; David 2002). Therefore, raster analysis of subtraction has been performed using the pre and post monsoon GRID surface of the region using 'cut/fill' function in 3D Analyst module of ArcGIS. The output is a GRID raster cell representing the thickness of the sediment of each cell. The detailed GIS modelling for estimation of Beach Sand Budget is depicted in Fig. 6.

The raster GRID surface generated in the system through subtraction process described above has been used to estimate the volume of the sediment in the area. The area covered by each $5 \mathrm{~m} \times 5 \mathrm{~m}$ grid cell is $25 \mathrm{~m}^{2}$. Since, each cell has a certain $\mathrm{Z}$-value representing the thickness of the sediment at that location, the volume of the sediment at each cell is calculated and subsequently all the cell-values are added up to arrive at the total volume of the sediment in the area. This computation is done through surface analysis 


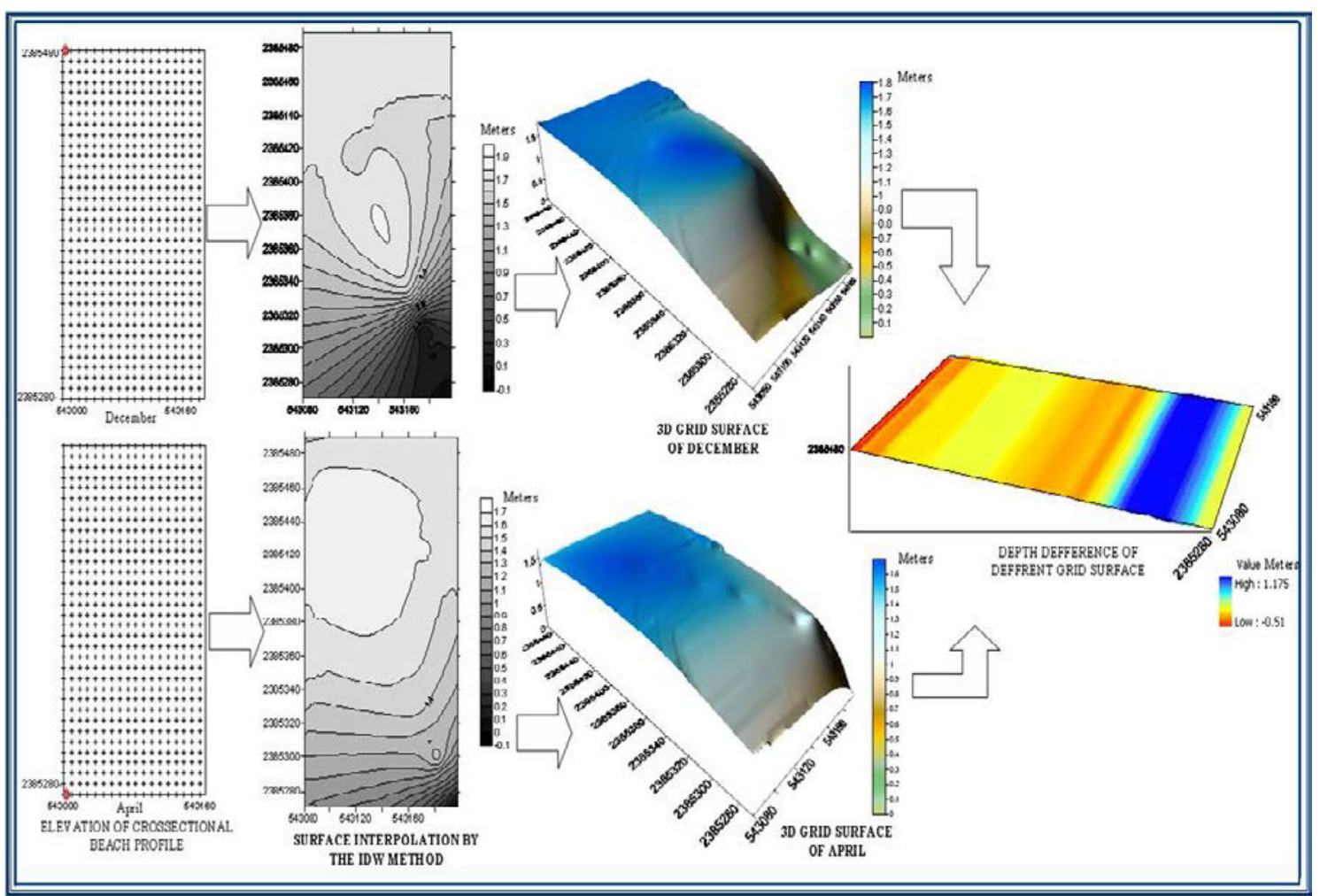

Fig. 6 GIS modelling for estimation of Beach Sand Budget

techniques in 3D Analyst module in ArcGIS. An alternative is to export the cell values in an ASCII format into a spreadsheet for calculation of total positive pixels (deposition) and negative pixels (erosion). Thus, the total volume of the sediment in the Midnapur and Balasore coast has been found to be about $+14,906,160.23 \mathrm{~m}^{3}$ (deposition), $-3,568,762.925 \mathrm{~m}^{3}$ (erosion) and sand budget was found $0.208 \mathrm{~m}^{3} / \mathrm{m}^{2}$ surface areas during pre and post monsoon season of 2009 .

\section{Result and discussion}

During the pre-monsoon months, waves and winds carry some energy to the beach with extra energy to suspend sediments and redistribute them in the near shore environment in medinipur-Balasore coastal region. Waves and Winds push water up on the leeward shore raising water levels. Return flow from this wind setup helps to carry sediment away from the shore (An Open University Course Team. 1989). In the present study it exhibits that the backwash has a little less energy to carry sediment down the beach so the beach gradually grows in size with the development of a berm. The pre-monsoon 2009 berm is eroded away and the sands deposited offshore during the monsoon to post monsoon 2009 seasons. The pre-monsoon beach profile is steeper and narrower which observed of our field study as depicted in Fig. 3. On the other hand, the major characteristics of post monsoon beach profile observed in the study region during the field survey are as follows (1) during post-monsoon calm weather with waves gently lapping the shore the beach grows in size, (2) waves surge up the shore face, (3) Thereafter the swash carries the sediment, (4) some of the backwash sinks into the sand and (5) the post-monsoon beach profile is broader and with a more gentle slope. So, post-monsoon and pre-monsoon beach profiles exhibits the dynamic coastal geomorphology and erosion/accretion of beach sand.

In the present study, six geomorphological units viz. (1) Geomorphological unit-I (Knakrapali to Subarnarekha River), (2) Geomorphological unit-II (Subarnarekha River to Talsari), (3) Geomorphological unit-III (Talsari to Digha River), (4) Geomorphological unit-IV (Digha River to Jalda River), (5) Geomorphological unit-V (Jalda River to Pichaboni River) and (6) Geomorphological unit-VI (Pichaboni River to Rasalpur River) along the Midnapur and Balasore coast have been selected depending on erosion, deposition, wave condition and different geomorphic features, such as river, tidal creek, mud flat, marshy land, vegetation etc. for the regional estimation of sand budget and beach recovery i.e. deposition and erosion analysis.

Obtained variations in beach profiles represent the periodical changes occurred during post and pre-monsoon 2008-2009 periods. The beaches were found to be 
Table 1 Erosion and Accretion (Beach Recovery) along the each crossectional beach profile

\begin{tabular}{|c|c|c|c|c|c|}
\hline Seasons & Location & Profile name & Profile volume $\left(\mathrm{m}^{3)}\right.$ & Volume change $\left(\mathrm{m}^{3)}\right.$ & Remarks \\
\hline Post-monsoon (Dec, 2008) & Knakrapali & BP-1 & 692.81 & 116.0127 & Accretion \\
\hline Pre-monsoon (April, 2009) & & BP-1A & 808.82 & & \\
\hline Post-monsoon (Dec, 2008) & Subarnarekha River mouth & BP-2 & 375.38 & 15.76 & Accretion \\
\hline Pre-monsoon (April, 2009) & & BP-2A & 391.15 & & \\
\hline Post-monsoon (Dec, 2008) & Talsari & BP-3 & 636.48 & 102.12 & Accretion \\
\hline Pre-monsoon (April, 2009) & & BP-3A & 738.61 & & \\
\hline Post-monsoon (Dec, 2008) & New Digha & BP-4 & 2104.19 & 30.183 & Accretion \\
\hline Pre-monsoon (April, 2009) & & BP-4A & 2134.38 & & \\
\hline Post-monsoon (Dec, 2008) & Old Digha & BP-5 & 373.59 & 76.906 & Accretion \\
\hline Pre-monsoon (April, 2009) & & BP-5A & 450.49 & & \\
\hline Post-monsoon (Dec, 2008) & Digha Mahona & BP-6 & 1049.49 & $(-) 24.042$ & Erosion \\
\hline Pre-monsoon (April, 2009) & & BP-6A & 1025.45 & & \\
\hline Post-monsoon (Dec, 2008) & Chandpur & BP-7 & 829.36 & 36.69 & Accretion \\
\hline Pre-monsoon (April, 2009) & & BP-7A & 866.05 & & \\
\hline Post-monsoon (Dec, 2008) & Sankarpur & BP-8 & 297.19 & $(-) 36.91$ & Erosion \\
\hline Pre-monsoon (April, 2009) & & BP-8A & 260.27 & & \\
\hline Post-monsoon (Dec, 2008) & Digha River to Sankarpur forest & BP-9 & 920.69 & $(-) 49.13$ & Erosion \\
\hline Pre-monsoon (April, 2009) & & BP-9A & 871.56 & & \\
\hline Post-monsoon (Dec, 2008) & Mandarmoni & BP-10 & 564.86 & $(-) 113.60$ & Erosion \\
\hline Pre-monsoon (April, 2009) & & BP-10A & 451.26 & & \\
\hline Post-monsoon (Dec, 2008) & Sirampur & BP-11 & 72.53 & 123.96 & Accretion \\
\hline Pre-monsoon (April, 2009) & & BP-11A & 196.49 & & \\
\hline Post-monsoon (Dec, 2008) & Arokbania & BP-12 & 148.32 & 61.66 & Accretion \\
\hline Pre-monsoon (April, 2009) & & BP-12A & 209.98 & & \\
\hline Post-monsoon (Dec, 2008) & Dadanpatrabar & BP-13 & 934.82 & 86.68 & Accretion \\
\hline Pre-monsoon (April, 2009) & & BP-13A & 1021.5 & & \\
\hline Post-monsoon (Dec, 2008) & Pichaboni & BP-14 & 989.13 & 36.11 & Accretion \\
\hline Pre-monsoon (April, 2009) & & BP-14A & 1025.24 & & \\
\hline Post-monsoon (Dec, 2008) & Hapipur & BP-15 & 597.30 & 197.39 & Accretion \\
\hline Pre-monsoon (April, 2009) & & BP-15A & 827.85 & & \\
\hline Post-monsoon (Dec, 2008) & Junput & BP-16 & 1346.48 & 142.6 & Accretion \\
\hline Pre-monsoon (April, 2009) & & BP-16A & 1489.09 & & \\
\hline Post-monsoon (Dec, 2008) & Kadua Mukundapur & BP-17 & 450.97 & 223.18 & Accretion \\
\hline Pre-monsoon (April, 2009) & & BP-17A & 674.15 & & \\
\hline Post-monsoon (Dec, 2008) & Kadua Mukundapur-2 & BP-18 & 552.58 & $(-) 72.56$ & Erosion \\
\hline Pre-monsoon (April, 2009) & & BP-18A & 480.02 & & \\
\hline
\end{tabular}

accreting at many places during the pre-monsoon 2009 survey period. Accumulation of sand usually occurs due to the natural action of waves, currents and wind by the formation of prominent berm nearby Subarnarekha River Mouth, Knakrapali, and Mandarmoni beaches. The beach width at different stations varies from 40 to 200 meters. Deposited or eroded volume of sand within different (BP 1-18), is accurately estimated using "eGIS: Survey Tool" of ArcGIS extension developed by CHL, USACE. The details of sand deposit and loss at all the eighteen beach profiles of Midnapur and Balasore coast during post monsoon and pre monsoon of 2008-2009 observations are illustrated in Table 1.

The prominent erosion has been observed nearby Digha inlet, Digha inlet to Shankarpur forest, Shankarpur, Mandarmoni, Sirampur, Kadua Mukundapur-2. Rest of the places shows prominent accretion as depicted in Fig. 7. These variations in the accretion and erosion can be attributed to the oceanographic processes and anthropogenic interventions, operating in the area in different seasons.

However regionally, overall accretion process is predominant of the present study during pre and post 


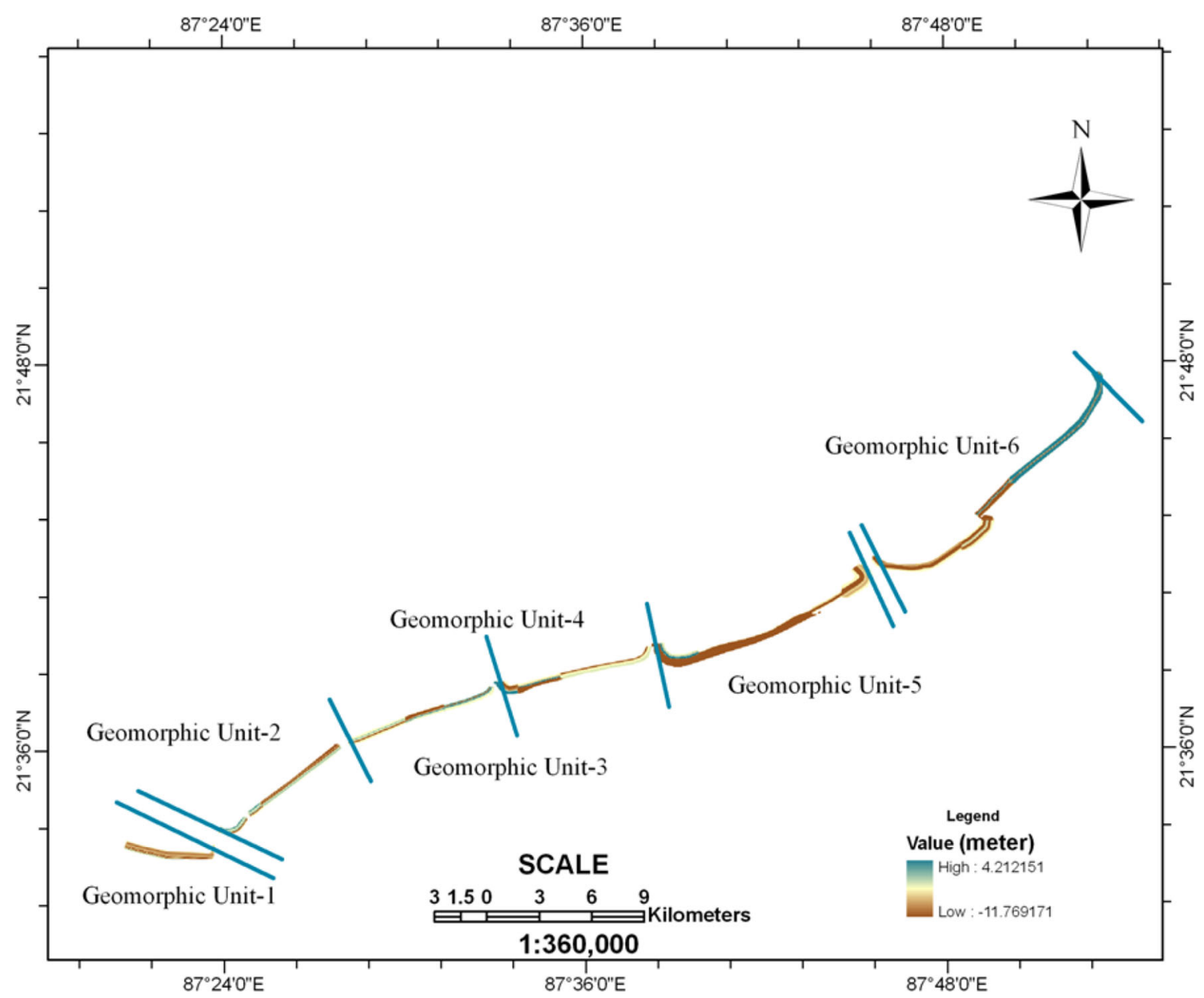

Fig. 7 Different of depth between pre and post monsoon 2009 grid surface along Midnapore-Balasore coastal region

Fig. 8 Regional identification of beach recovery along Midnapur to Balasore Coast

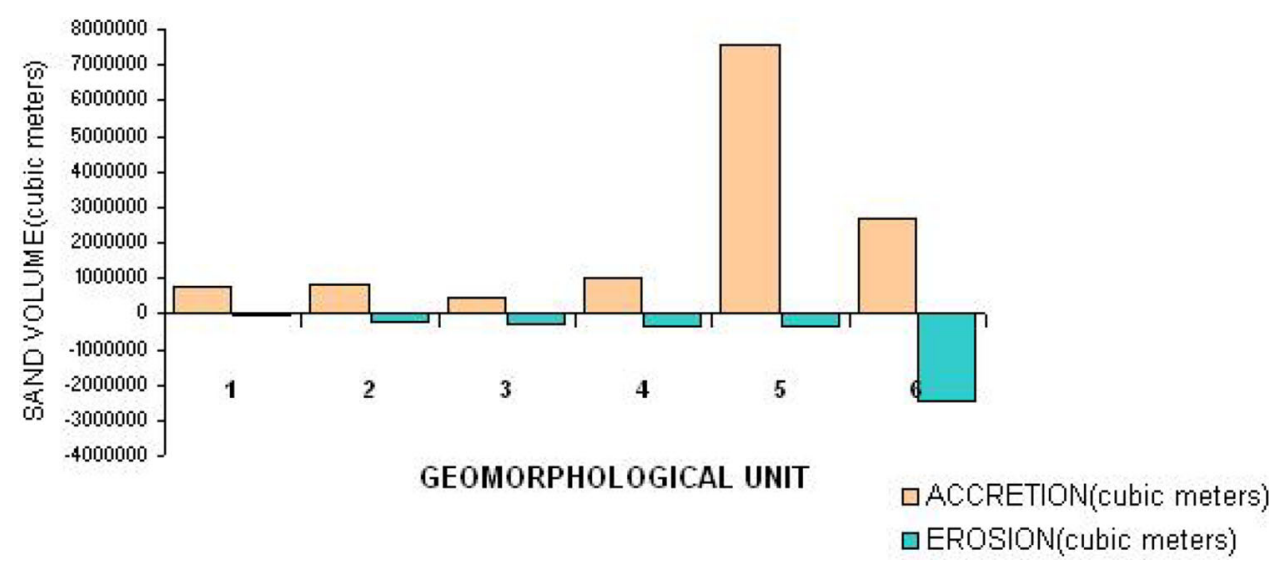

monsoon seasons. Surface erosion is mainly prominent within Geomorphological Unit-IV $\left(-363,159.34 \mathrm{~m}^{3}\right)$ as depicted in Fig. 8. Total accretion and erosion of the study area are $14,906,160.23 \mathrm{~m}^{3}$ and $(-)-3,552$, $625.205 \mathrm{~m}^{3}$ respectively. The overall gain, that is, sand budget per unit surface area $\left(\mathrm{m}^{3} / \mathrm{m}^{2}\right)$ in the study area, is $0.208 \mathrm{~m}^{3} / \mathrm{m}^{2}$ during post monsoon (December 2008) to pre-monsoon (April 2009) period and sand budget per Table 2 . $\mathrm{m}^{2}$ surface area of all profiling data points are given in 


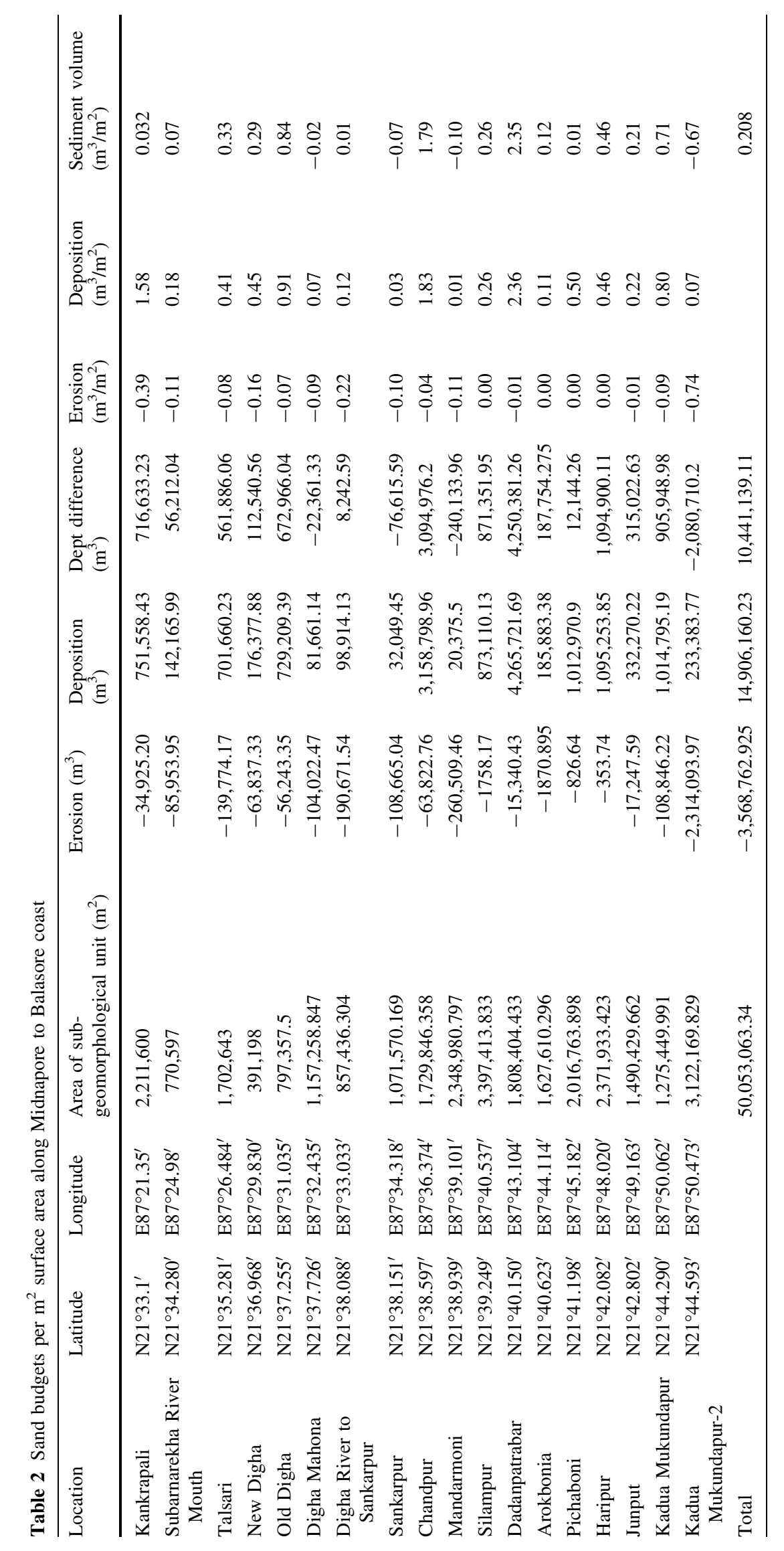




\section{Conclusions}

Generation of high resolution Digital Elevation Model ( $5 \mathrm{~m}$ resolution DEM) has been carried out from a few manually surveyed beach profile data acquired during pre and post monsoon seasons. Geographical Information System (GIS) based digital elevation change model has been used for estimation of eroded or deposited sand. In the present study area, pre-monsoon beach is found to be predominantly depositional compared to post-monsoon beach but dunes are erosional for all cases. The overall sand budget estimation indicates that the $113 \mathrm{~km}$ long coastal stretch has gained $11,353,535.03 \mathrm{~m}^{3}$ of sand during post monsoon (December 2008) to pre-monsoon (April 2009) period. The overall gain, that is, sand budget per unit surface area $\left(\mathrm{m}^{3} / \mathrm{m}^{2}\right)$ in the study area is $0.208 \mathrm{~m}^{3} / \mathrm{m}^{2}$ during post monsoon (December 2008) to pre-monsoon (April 2009) period.

Acknowledgements The authors would like to thank Prof. A.K. Bhattacharya, IIT Kharagpur for organization, support and cooperation in the coastal field work in Midnapore - Balasore coastal area during 2008-2009. Special thanks to Anonymous reviewers and editor for their constructive comments and useful suggestions that benefited the manuscript.

\section{References}

An Open University Course Team (1989) Waves, tides and shallowwater processes. Pergamon Press, England

Anthony EJ, Vanchee S, Ruz M-H (2006) Short-term beach-dune sand budgets on the north sea coast of France: sand supply from shoreface to dunes, and the role of wind and fetch. Geomorphology 81(2006):316-329

Bhattacharya A, Sarkar S, Bhattacharya A (2003) An assessment of coastal modification in the low-lying tropical coast of NorthEast INDIA and role of natural and artificial forcings. In: International conference on estuaries and coasts, Hangzhou

Bonham-Carter GF (1994) Geographic information systems for geoscientists: modelling with GIS. Pergamon, Oxford, p 398

Bryant RH (1986) Phisical geography. Rupa \& Co Publication, Kolkata

Burrough PA, McDonnell RA (1998) Principles of geographical information systems. Oxford University Press, Oxford, p 333

Cracknell AP, Hayes LWB (1991) Introduction to remote sensing. Taylor \& Francis, London, UK, p 293

Cracknell AP (1999) Remote sensing techniques in estuaries and coastal zones an update. Int J Remote Sens 20(3):485-496

Chrzastowski MJ (2005) Chicagoland geology and the making of a metropolis, Illinois State Geological Survey. Open File Series OFS 2005-9

Chang K-T (2007) Introduction to geographic information systems, 4th edn. Tata McGraw-Hill Publishing Company Limited, New Delhi
Choowong M, Phantuwongraj S, Charoentitirat T, Chutakositkanon V, Yumuang S, Charusiri P (2004) Beach recovery after 2004 Indian Ocean tsunami from Phang-nga, Thailand. Department of Geology, Faculty of Science, Chulalongkorn University, Bangkok, 10330, Thailand

David LV (2002) Practical GIS analysis. Taylor \& Francis Publication, London

Dean RG (1977) Equilibrium beach profiles: U.S. Atlantic and Gulf coasts. Department of Civil Engineering, Ocean Engineering Report No. 12. University of Delaware, Newark, DE

Dubois RN (1988) Seasonal changes in beach topography and beach volume in delaware. Mar Geol 81(1988):79-96

Esri (2003) ArcGIS geostatistical analyst documentation, ArcGIS User Manual, ESRI, USA. http://www.esri.com

Ganesan P, Gaonkar SS (2006) Seasonal beach profiling along Malvan and Kotharwadi coast, southern Maharashtra central west coast of India, NIO/TR-04/2006. pp 1-42

Huang LR, Yang GH, Hu HM (1991) The isostatic datum for studying of the sea level changes along the coast of China. Seismol Geol 13:8-14

Ikeda M, Dobson FW (2005) Oceanographic application of remote sensing. CRC Press, London

Isaaks EH, Srivastava RM (1989) An introduction to applied geostatistics. Oxford University Press, Oxford

Maiti S, Bhattacharya AK (2009) Shoreline change analysis and its application to prediction: a remote sensing and statistics based approach. Mar Geol 257:11-23

Meentemeyer RK, Moody A (2000) Automated mapping of conformity between topographic and geological surfaces. Comput Geosci 26(7):815-829

Pacheco A, Vila-Concejo A, Ferreira O, Dias JA (2008) Assessment of tidal inlet evolution and stability using sediment budget computations and hydraulic parameter analysis. Mar Geol 247(2008):104-127

Paul AK (2002) Coastal geomorphology and environment: Sundarban coastal plain, Kanthi coastal plain and Subarnarekha delta plain. ACB Publication, Kolkata

Pethick J (1990) An introduction to coastal geomorphology. Arnold Publishers, New Delhi

Ramana Murthy MV, Mani JS, Subramanian BR (2008) Evolution and performance of beach fill at Ennore Seaport, Southeast Coast of India. J Coast Res 24(1A):232-243

Ramasamy S, Kasturirangan K (2005) Remote sensing in geomorphology. NIPA Publication, New Delhi

Rao KN, Rao UB, Rao TV (2008) Estimation of sediment volume through Geophysical and GIS analyses. J Ind Geophys Union 12(1):23-30

Selby MJ (1985) Earth's changing surface. Oxford University Press, New York

Sener E, Davraz A, Sener S (2009) Investigation of Aksehir and Eber Lakes (SW Turkey) coastline change with multitemporal satellite images. Water Resour Manag 24(4):727-745. doi:10.1007/ s11269-009-9467-5

Singh RL, Singh RPB (1950) Element of practical geography. Kalyani Publishers, New Delhi

Verbyla D, Hammond T (2002) How to lie with an error matrix. Remote Sens Image Anal. http://nrm.salrm.uaf.edu/dverbyla/ online/errormatrix.html 